\title{
ケーソン護岸連結目地内での流体共振特性に及ぼす入射角の影響
}

\section{Effects of Incident Wave Angle on Resonant Fluid Motions in Joint Gaps of Caisson-type Seawall}

\author{
斎藤武久 $^{1} \cdot$ 吉岡和利 $^{2}$
}

\author{
Takehisa SAITOH and Kazutoshi YOSHIOKA
}

\begin{abstract}
In this study, fluid resonance in the narrow joint gaps of a caisson-type seawall is investigated experimentally and theoretically. In particular, focus is placed on the effect of incident wave angle for the occurrence condition of the fluid resonance and the amplification of wave height in the gaps at resonance. 3-D wave basin with a snake-type wave generator is used in the experiments, and the theoretical analysis is carried out using the method of matched asymptotic expansions. Consequently, it is found that the incident wave period and the amplification on wave height in the gaps as fluid resonance occurred are independent of incident wave angle and can be predicted using the knowledge subject to the case that the incident wave progress perpendicular to the seawall.
\end{abstract}

\section{1. 緒論}

波と構造物との干渉による波動場を正確に把握するこ とは, 構造物の機能・性能設計において構造周辺の流体 運動や外力特性を的確に設定する上で必要不可欠である. ケーソン護岸の場合, 背後域の安全性確保の観点から, 護岸への波の打ち上げ高や越波流量の評価などが積極的 に行われ，これまで多くの知見が整理されている（例え ば, 合田, 2008 ; 土木学会海岸工学委員会, 2000).

一方で, ケーソン護岸背後域での陥没の発生は, 護岸 前面での洗掘や中詰土砂の吸出し, さらに, ケーソン連 結目地を介した裏込め土砂の流出と関連した複雑な問題 として, そのメカニズムの解明に向けて多くの議論（例 えば, 高橋ら, 1995 ; 重村ら, 2002）が行われている. しかしながら, 現象は, 波と構造物, さらに砂地盤とい った多くの要因が複雑に関連しているため, 発生した陷 没の原因を特定するには困難な事が多く, 現実問題とし て試行錯誤的な対策により被災軽減を行っているのが現 状と言える.

連結目地に着目した場合，防砂板の破損に伴う背後砂 の流れ出しが主な事故原因と報告された大蔵海岸陷没事 故（土木学会海岸工学委員会, 2002）を教訓に, 関連し た多くの検討事項が挙げられている. 中でも, 防砂板に 対して主要な外力となる目地内の波力を評価することは 重要な事項であり, 再発防止に向けて, 連結目地内の流 体運動を正確に把握することが必要不可欠と考えられる.

この連結目地内での流体運動に関して, 著者ら（斎藤

\begin{tabular}{lll}
\hline 1 正会員 & 博(工) & $\begin{array}{l}\text { 金沢大学准教授理工研究域環境デザイン } \\
\text { 学系 }\end{array}$ \\
2 & 修(工) & 金沢市都市整備局
\end{tabular}

ら，2005，2006）は，規則波および不規則波が護岸へ直 交入射する場合を対象に理論解析および室内実験で検討 し, 目地のような微小間隙内でも流体共振現象が発生す ることを見出している, さらに, 流体共振発生時の目地 内波高は極端に増幅され, 規則波の直交入射の場合, 目 地内波高は静穏時入射波高の 8 倍に達するなど, 静穏時 にも関わらず目地内では荒天時に相当する流体運動が発 生する可能性を明らかにしてきている.

本研究では, 護岸への直交入射の場合に得られた流体 共振特性を基礎に研究を発展させ, 実際の海象条件で重 要な要素となる波向きに着目し, 入射角の変化が目地内 の流体共振特性に及ぼす影響を実験的および理論的に考 究する.

\section{2. 実験装置および実験方法}

図-1に実験装置の概要を示す。実験には，一端にスネ

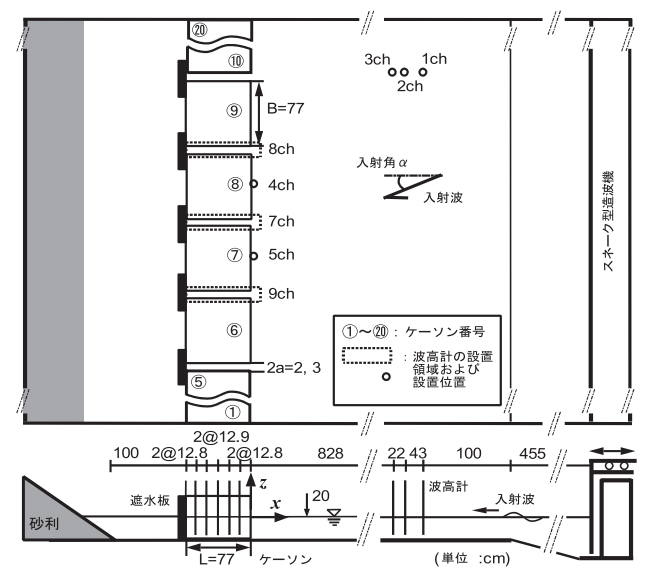

図-1 実験装置の概要 


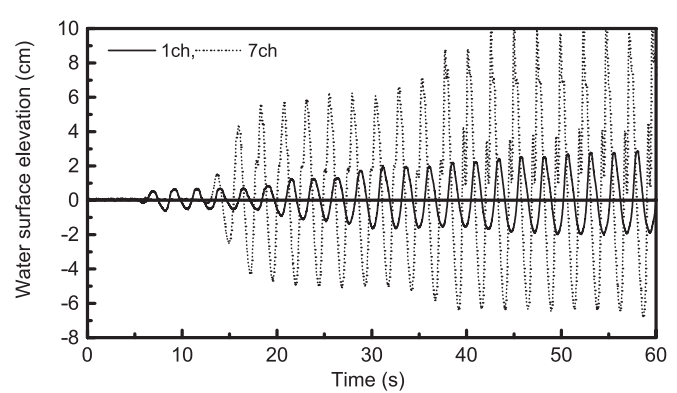

図-2 造波開始直後から計測した目地外部（ch.1）および目地 内岸側端部 (ch.7, $x=-L \mathrm{~cm})$ での水面変動の時間変化 記録の例 $\left(T=2.44 \mathrm{~s}, \alpha=0^{\circ}\right)$

ーク型造波機が装備された長さ $22 \mathrm{~m}$, 幅 $17 \mathrm{~m}$, 高さ $1 \mathrm{~m}$ の 平面水槽を用いた. 水槽岸側部に長さ $L=77 \mathrm{~cm}$, 幅 $B=$ $77 \mathrm{~cm}$, 高さ $D=40 \mathrm{~cm}$ の矩形ケーソン（ケーソン番号 5 か ら 10 までがアクリル製，1から4および11から20は木製） と遮水板からなるケーソン護岸を設置し, 水深を $h=$ $20 \mathrm{~cm}$ に固定した. 入射波には周期 $T=0.83 \sim 4 \mathrm{~s}$, 波高 $H$ $=1 \sim 1.5 \mathrm{~cm}$, 入射角 $\alpha=0 \sim 15^{\circ}$ の規則波を用い, 目地幅 を $2 a=3$ および $2 \mathrm{~cm}$ とて変化させ, 合計 152 ケースの実 験を行った. 水面変動の時間変化記録は 3 つの目地内お よび 5 箇所の目地外で取得し, 目地内の水面形状の画像 データをデジタルビデオカメラで取得した。なお，本実 験で使用する造波機は位置制御で造波が行われる。この ため，造波開始からしばらくして護岸および造波板との 間で多重反射が発生する。図-2に，造波開始直後から ch.1およびch.7（目地岸側端部， $x=-L \mathrm{~cm}$ ）で計測され た水面変動の時間変化記録を例示するが, 目地外部領域 である ch. 1 では，造波開始から約 $5 \mathrm{~s}$ 程度で計測位置へ入 射波が到達し，約 $20 \mathrm{~s}$ 程度までは一定の波高が計測され ている。ただし，約 $25 \mathrm{~s}$ 後以降では護岸からの反射波さ らに造波板からの再反射波による多重反射の状態が発生 し, 目地内のch.7でも, 約 40s 後以降には, 護岸前面で の多重反射の影響を反映した水面変動特性となってい る.このため, 本実験では, 水面変動データの取得を造 波開始直後からの約 60 秒間とし, 取得データから波高を 計算する際には，取得された各計測位置でのデータをそ れぞれ目視により確認しながら，線形波動論に基づいた 波の伝達時間を参考にして多重反射前の時間における平 均波高を採用した。後述するように，目地内での波高増 幅率は, 目地内平均波高 $H_{g}$ を入射波高で除した無次元波 高で評価する。この時の入射波高には, 護岸模型を取り 除き，それぞれの連結目地前面位置で新たに取得したデ ータを用いて計算した平均波高を採用している。

\section{3. 実験結果および考察}

図-3（a）および（b）に，入射角が $0^{\circ}$ の場合に目地外

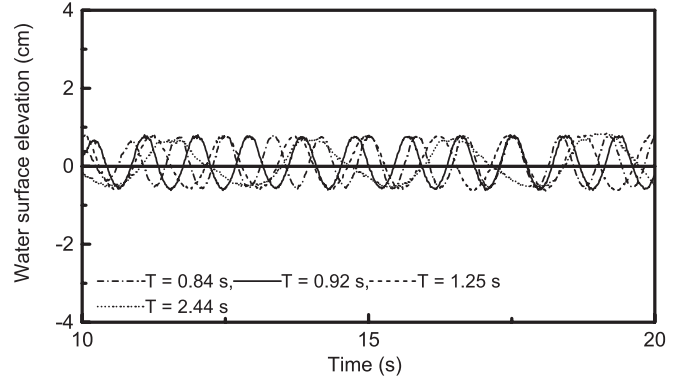

(a) 目地外部 (ch.1)

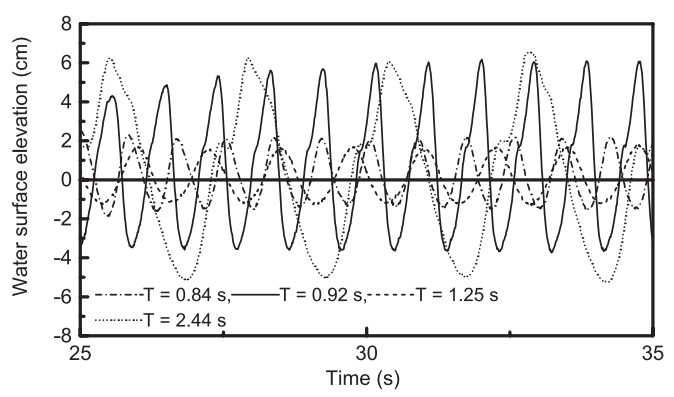

(b) 目地内岸側端部 (ch.7)

図-3 目地外部 (ch.1) および目地内岸側端部 (ch.7, $x=-L \mathrm{~cm})$ で計測された水面変動の時間変化記録 $\left(\alpha=0^{\circ}\right)$

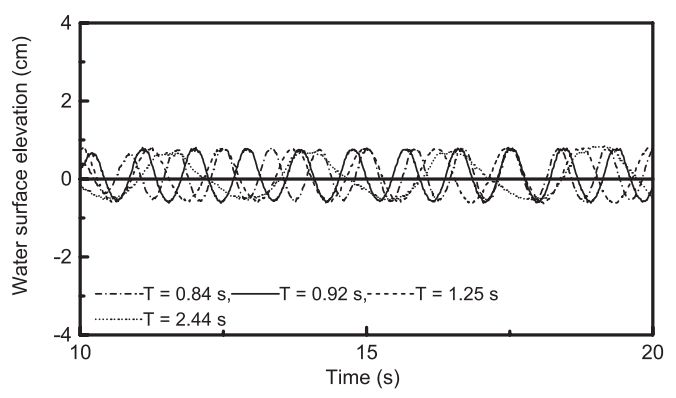

(a) 目地外部 (ch.1)

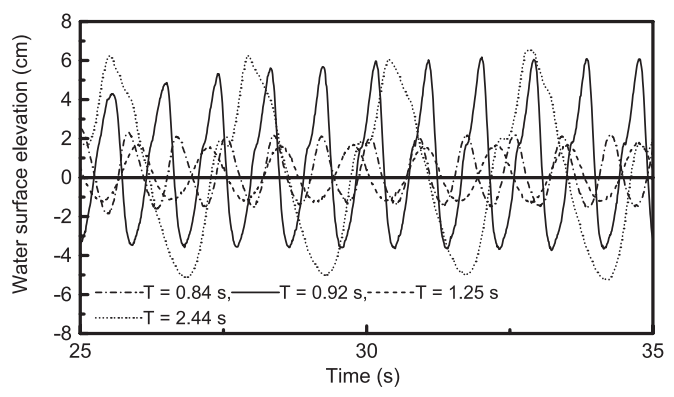

(b) 目地内岸側端部 (ch.7)

図-4 目地外部（ch.1）および目地内岸側端部 (ch.7, $x=-L \mathrm{~cm})$ で計測された水面変動の時間変化記録 $\left(\alpha=10^{\circ}\right)$

部（ch.1）および目地内岸側端部（ch.7, $x=-L \mathrm{~cm}$ ) で計 測された水面変動の時間変化記録を例示する。図中の横 軸は，造波開始からの経過時間を表している。図より， 目地外部では, 対象とする全ての入射波周期において, 


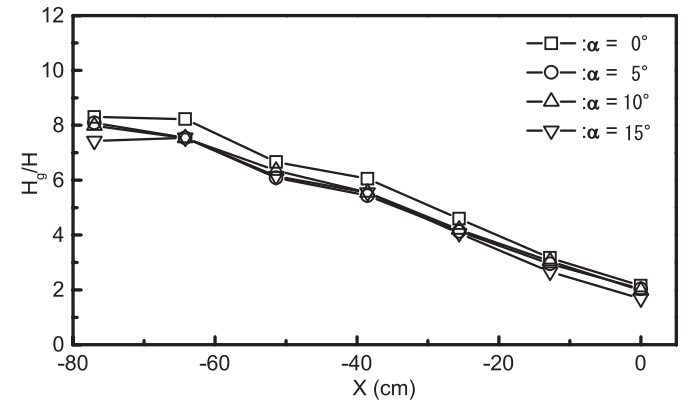

(a) 1 次モードの流体共振 $(T=2.44 \mathrm{~s})$

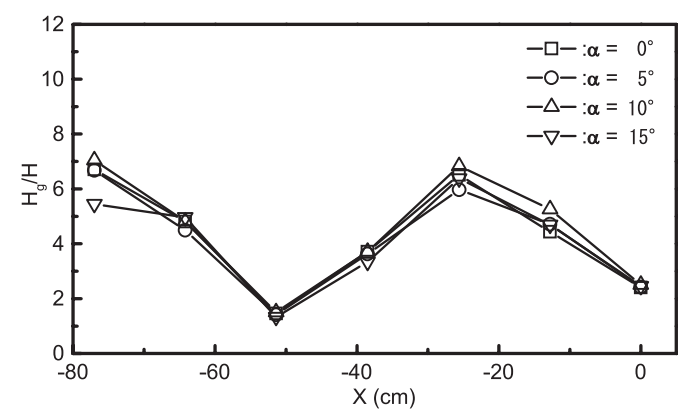

(b) 2 次モードの流体共振 $(T=0.92 \mathrm{~s})$

図-5 目地内平均波高の空間分布特性（ch.8）

水面変動は非常に小さな值となっているが, 目地内では, $T=2.44 \mathrm{~s}$ と $0.92 \mathrm{~s}$ の場合に, 水面変動が極端に増幅されて いることが分かる.なお，T=2.44s および $0.92 \mathrm{~s}$ の場合に， 目地内ではそれぞれ, 目地岸側端部を腹とする1次およ び2次モードの流体共振に近い水面形状の特性を示し, 全てのケースにおいて目地内の水面変動周期は入射波周 期に一致していた。これらの結果は，特定の入射波周期 に対応した目地内での流体共振の発生を示すものであ り，2次元水槽で実施した既往の実験結果（斎藤ら, 2005）とも一致している。一方, 入射角が $10^{\circ}$ の場合の 結果を図-4に示す。図より，入射角 $0{ }^{\circ}$ の場合と同様に， $T=2.44 \mathrm{~s}$ と $0.92 \mathrm{~s}$ の場合のみに目地内で極端な水面変動の 増幅が確認できる. 目地内の水面形状に関しても, $0^{\circ}$ の 場合と同様な共振モードが確認されている.

次に, 入射角の変化に伴う目地内平均波高 $H_{g}$ の空間分 布特性を図-5（a）および（b）に示す。図はそれぞれ， 図-3 と図-4で目地内水面変動に極端な増幅が確認された $T=2.44 \mathrm{~s}$ および $0.92 \mathrm{~s}$ の場合における $H_{g}$ の空間分布であ る. 図より, $T=2.44 \mathrm{~s}$ の場合, 目地岸側端部を腹とする 1次モード，さらに，T=0.92s の場合は 2 次モードに近い 波高分布の発生が確認できる。加えて, 各計測位置での 波高増幅率 $H_{g} / H$ は, 入射角の変化に関わらずほほ等し いことが分かる．以上の結果は，入射角の違いによらず， 目地内での流体運動特性が入射波周期に大きく依存する ことを示している.つまり，幅が狭い目地内においては，

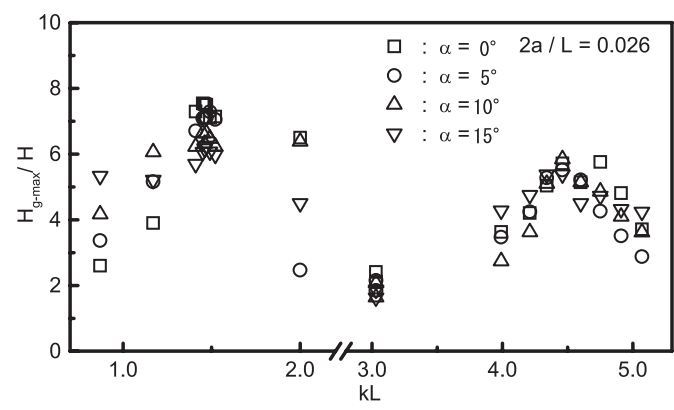

(a) 目地幅 $2 a=2 \mathrm{~cm}$

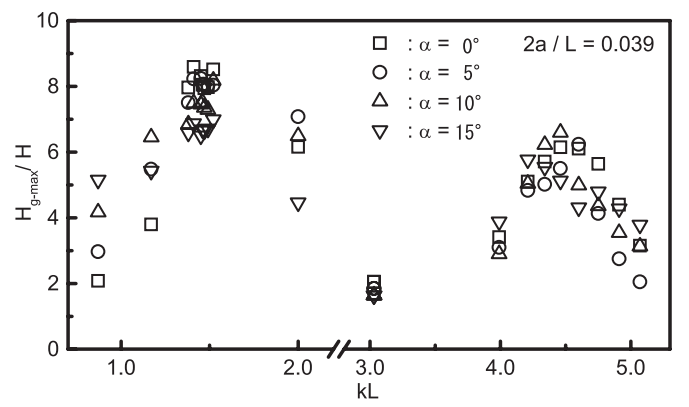

(b) 目地幅 $2 a=3 \mathrm{~cm}$

図-6 入射波の無次元波数 $k L$ および目地内での波高増幅率 $H_{g-\max } / H$ との関係（実験結果, ch.8）

回折などの面的な影響を受けることなく，流体運動が 2 次元的で, 入射波の振動特性のみが目地内に伝播するこ とを示す結果となっている。なお，同一の入射波周期で あっても, 入射波高の変化に伴って波高増幅率が変化す ることも同時に確認している．この点に関しては，共振 発生時の波高の規模の予測と関連して, さらに検討が必 要である。

目地内での流体共振の発生条件に関連して，入射波周 期と目地岸側端部での波高増幅率 $H_{\mathrm{g}-\text { max }} / H$ との関係をよ り詳細に検討するため, 入射波の無次元波数 $k L$ と $H_{\mathrm{g}-\text { max }} /$ $H$ との関係を図-6（a）および（b）に示す。（a）が目地 幅 $2 \mathrm{~cm}$ の場合であり，（b）が目地幅 $3 \mathrm{~cm}$ の場合である. 図より, 1 次モードの流体共振の発生の場合, $k L=1.5$ 付 近の一定の值で増幅率が最大となり, 今回対象とした実 験条件の範囲では, 目地内での顕著な流体共振の発生条 件に及ぼす入射角の影響は確認できない。 なお， 2 次モ ードの範囲では, 増幅率が最大となる $k L$ の值にばらつき が見られる。これは，入射波周期 $T$ の変化を $k L$ が拡大表 記するためであり, 増幅率が最大となる周期の範囲は 1 次モードの場合と同様に $0.05 \mathrm{~s}$ 以内であり，ほぼ一定の入 射波周期の場合に，目地内波高が最大となっていた。

\section{4. 理論解析}

入り口の狭い矩形港湾内の水面共振発生条件の誘導手 法（Mei，1989）に倣い，漸近接合法を用いて目地内で 


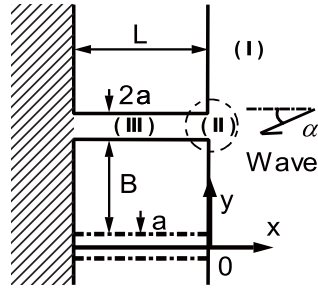

(a) 領域分割

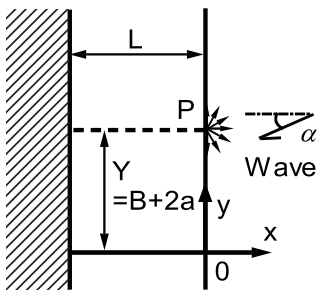

(b) 外部領域
図-7 座標系

の速度ポテンシャルを導き, 入射波の無次元波数 $k L$ $(k$ : 入射波の波数) と目地内の無次元水面変位 $|\eta / H|$ と の関係，すなわち流体共振スペクトルを誘導する。ただ し，Mei（1989）が採用した目地沖側端部を原点とする 座標系では，入射波速度ポテンシャルを原点へ漸近展開 することが，入射角を直交入射へと拘束し，入射角の影 響を取り込むことができない. そこで, 本研究では目地 位置を図-7（a）に示すように変更して新たに漸近速度ポ テンシャルを誘導し, 入射角の影響を取り込む.ただし， 入射角の変化が目地内での流体運動に与える影響の有無 に着目することを目的に, ここでは単一の目地のみが存 在する場合を対象に理論展開を行う。このことは, 複数 の連結目地が存在する本実験条件に対する解析の第一段 階として位置づけられる.

この時, 解析領域を (I) 入射波領域, (II) 目地端部領 域および（III）目地内部領域（図-7（a）を参照）に分割 し, 各領域における速度ポテンシャルを次式で定義する.

$$
\begin{aligned}
& \phi_{(I)}=-\frac{i g H}{\sigma} e^{-i k y \sin \alpha} \cos (k x \cos \alpha)+Q_{P} H_{0}^{(1)}(k r) \cdots(1) \\
& \begin{array}{c}
\phi_{(I I)}=\operatorname{Re}_{i} W(\tau)=\operatorname{Re}_{i}(M \ln \tau+C), \\
x+i(y-Y)=\frac{2 a}{\pi}\left[-i\left(\tau^{2}-1\right)^{\frac{1}{2}} \quad \cdots \cdots(2)\right. \\
\left.\quad+\ln \left\{\frac{\tau}{\left(\tau^{2}-1\right)^{1 / 2}+i}\right\}\right]
\end{array} \\
& \phi_{(I I I)}=E\left(e^{-i k(x+L)}+e^{i k(x+L)}\right) \quad \cdots \cdots \cdots \cdots \cdots \cdots \cdots \cdots(3)
\end{aligned}
$$

ここに，iは虚数単位であり， $\sigma$ は分散関係 $\sigma^{2}=g k \tanh k h$ （ $\mathrm{g}$ は重力加速度）を満足する角振動数である. また, $H_{0}$ ${ }^{(1)}(\mathrm{kr})$ は 0 次第一種ハンケル関数を表し, $r$ は目地位置 $P$ 点 (後述する湧き出し点の位置) から対象点までの距離 を表す。なお，目地の存在が波動場に及ぼす影響は，目 地を取り除いた連続直立壁上に点湧き出しを設けること によって考慮し（図-7（b）を参照), 式（2）の目地端部 領域における流体運動の記述では, はシュワルツークリ ストッフェル変換を用いている.

式中の未知数 $Q_{P}, M, C$ おびは, 上述の速度ポテンシ ヤルから, 隣り合う領域への以下の漸近速度ポテンシャル

$$
\begin{gathered}
\left.\phi_{(I) \rightarrow(I I)}\right|_{P \rightarrow P_{0}}=-\frac{i g H}{\sigma} e^{-i k Y \sin \alpha}+Q_{P}\left(1+\frac{2 i}{\pi} \ln \frac{\gamma k r}{2}\right) \\
\left.\phi_{(I I) \rightarrow(I)}\right|_{x>0}=M \ln \frac{\pi r}{2 a}+C \quad \ldots \ldots \ldots \ldots \ldots \ldots \ldots \ldots \ldots \ldots \ldots \ldots \ldots \ldots \ldots \ldots \ldots \ldots \ldots \\
\left.\phi_{(I I) \rightarrow(I I)}\right|_{x<0}=M \frac{\pi x}{2 a}-M \ln \frac{e}{2}+C \cdots \ldots \ldots \ldots \ldots \\
\left.\phi_{(I I I) \rightarrow(I I)}\right|_{x \rightarrow 0}=E\left(e^{-i k L}+e^{i k L}\right)+i k E\left(e^{-i k L}+e^{i k L}\right) x \\
+\cdot \cdots \cdot O(k x)^{2}
\end{gathered}
$$

を領域間でそれぞれ等值することで得られる以下の関係 式から決定される。

$$
\begin{aligned}
& E\left(e^{-i k L}+e^{i k L}\right)=C-M \ln \frac{e}{2} \\
& i k E\left(-e^{-i k L}+e^{i k L}\right)=\frac{\pi M}{2 a} \\
& -\frac{i g H}{\sigma} e^{-i k Y \sin \alpha}+Q_{P}\left(1+\frac{2 i}{\pi} \ln \frac{\gamma k r}{2}\right)=C+M \ln \frac{\pi \gamma}{2 a} \\
& \frac{2 i}{\pi} Q=M
\end{aligned}
$$

さらに，目地内の振幅に関係するを整理し，式（3）へ 代入することで, 目地内部領域での速度ポテンシャルお よび水面変動は次式のように誘導できる.

$$
\begin{aligned}
\phi_{(I I I)} & =-\frac{i g H}{\sigma} e^{-i k Y \sin \alpha} \frac{\left(e^{-i k(x+L)}+e^{i k(x+L)}\right)}{(1+k a R) e^{-i k L}+(1-k a R) e^{i k L}} \\
& , R=1+\frac{2 i}{\pi} \ln \frac{2 \gamma k a}{\pi e} \\
\eta / H & =\frac{U V-i U W}{S-i T} \\
S & =\cos k L+k a \frac{2}{\pi} \ln \frac{2 \gamma k a}{\pi e} \sin k L, \\
T & =k a \sin k L, \quad U=\cos k(x+L), \\
V & =\cos (k Y \sin \alpha), W=\sin (k Y \sin \alpha)
\end{aligned}
$$

ここに, $\gamma$ はオイラー定数を表す. 目地内の水面変動に 関する流体共振スペクトルは，式（13）の絶対值をとる ことで，次式のように導かれる.

$$
\begin{aligned}
|\eta / H| & =\frac{U \sqrt{(V S+W T)^{2}+(V T-W S)^{2}}}{S^{2}+T^{2}} \\
& =\frac{U \sqrt{S^{2}+T^{2}}}{S^{2}+T^{2}}
\end{aligned}
$$

ここで，流体共振スペクトル式（14）に着目すると，目 地内の無次元水面変位に対応する $|\eta / H|$ の值は, 入射角 には無関係に決定されることが分かる，つまり，式（12） 中で見られる入射角の違いは, 異なる目地間での水面変 


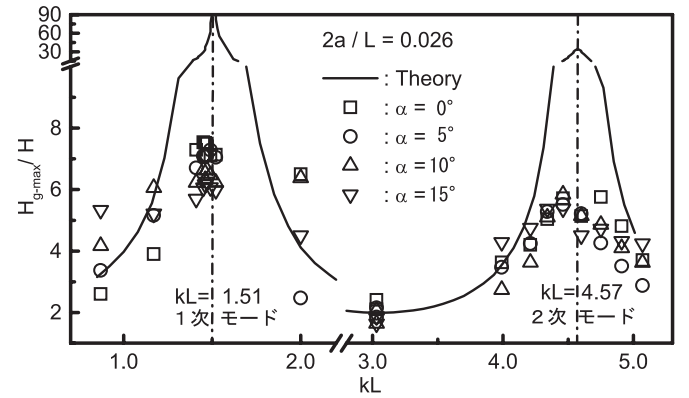

(a) 目地幅 $2 a=2 \mathrm{~cm}$

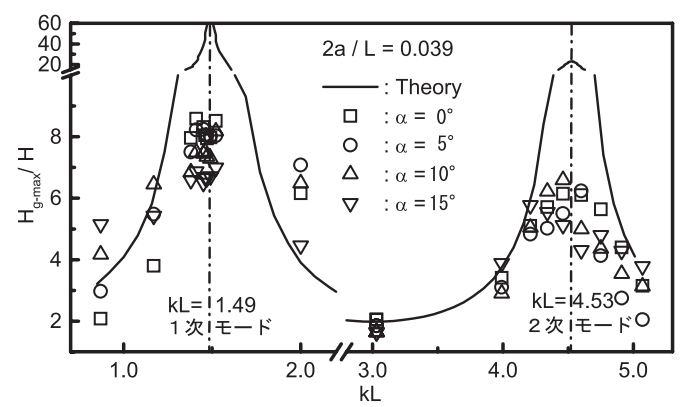

(b) 目地幅 $2 a=3 \mathrm{~cm}$

図-8 入射波の無次元波数 $k L$ および目地内での波高増幅率 $H_{g-\max } / H$ との関係（実験結果および理論解析結果, ch.8)

動の位相差には寄与するものの, 目地内での水面変動の 大きさには寄与しないことを示している. なお, 式（14） は護岸への直交入射を仮定して誘導された既往の共振ス ペクトル（斎藤ら，2005）において, 目地の存在を1つ にした場合の関係式と同じであった。このことは, 目地 内での流体共振の発生条件が，入射角に関係なく，直交 入射の場合の結果より予測可能であることを示してい る.

\section{5. 理論解析結果および考察}

理論解析では, 目地内の速度ポテンシャルが，入射角 $\alpha$ を含んで式（12）のように誘導され，異なる目地内で の水面変動に発生する位相差として入射角が寄与し, 入 射角の違いは目地内の共振スペクトルには無関係である ことが明らかになった。 また，共振スペクトルがピーク となる共振発生条件は, 入射角が $0{ }^{\circ}$ の場合と同様であっ た。ここで, 理論解析結果の有効性を確認するため, 図-8（a）および（b）に目地幅が $2 \mathrm{~cm}$ およ゙ $3 \mathrm{~cm}$ の場合 の共振スペクトルに関する実験結果と式（14）から得ら れる共振スペクトルの理論值を併記して比較する.なお, 図中の理論值は式（14）を2倍した無次元波高である. 戝より，スペクトルが極值となる $k L$ の值は実験結果と良 好に一致し, 理論解析結果の有効性が確認できる。この 結果は, 同時に, 他の目地の存在が対象とする目地内で
の流体運動へ及ぼす影響は必ずしも大きくないことを示 している.

\section{6. 結論}

本研究では, 護岸への直交入射の場合に得られた目地 内での流体共振特性を基礎に研究を発展させ，実際の海 象条件で重要な要素となる波向きに着目し, 入射角の変 化が目地内の流体共振特性に及ぼす影響を実験的および 理論的に考究した.

平面水槽実験より, 目地内で最も顕著な流体共振が発 生する入射波周期および波高増幅率は, 入射角の違いに 関わらずほぼ一定であり，2次元水槽実験による結果と 同様な傾向を示すことが明らかになった。

漸近接合法を用いた理論解析から，入射角の影響は， 異なる目地間での水面変動の位相差には寄与するもの の, 目地内での流体共振の発生条件および水面変動の大 きさには寄与しないことが導かれた。 以上の結果は, 平 面水槽実験の結果を良好に再現するとともに，直交入射 の場合を対象とした結果を用いることで目地内での流体 共振特性を十分に予測評価が可能であることを示唆する ものであった。

最後に本研究を行うに際し, 実験施設（北陸電力技術 開発研究所）の使用では，北陸電力土木部の柴田俊治部 長に多大なご配慮をいただいた. また, 愛知県庁の小森 祐輝氏（当時, 金沢大学学部生), 福井県庁の高橋卓氏 (当時, 金沢大学学部生) には, 実験およびデー夕の整 理に終始助力いただいた。ここに記して厚く謝意を表す。 なお, 本研究の一部は前田工学記念財団による研究助成 によるものであることを記して謝意を表す。

\section{参 考 文 献}

合田良實（2008）：耐波工学 港湾構造物の耐波設計，鹿島 出版, 430p.

斎藤武久·國田 治・G.P.Miao ·石田 啓 (2005) : ケーソ ン護岸連結目地内での流体共振スペクトルおよび共振発 生条件, 海岸工学論文集, 第52巻, pp.796-800.

斎藤武久·藤井 誠・G.P.Miao - 石田 啓 (2006) : 不規則 波の入射に伴うケーソン護岸連結目地内での流体共振特 性, 海岸工学論文集, 第 53 巻, pp. 495-500.

重村利幸 - 滝口和男 · 多田 毅 - 林建二郎 - 藤間功司 （2002）：防波護岸背後からの土砂吸出しに関する基礎的 研究, 海岸工学論文集, 第49巻, pp.871-875.

高橋重雄 - 鈴木高二朗 - 徳淵克正 - 岡村知光 - 下迫健一郎 善 功企・山崎浩之 (1995) : 護岸の吸出しに関する水 理実験，港研報告，35巻，2号，pp.3-63.

土木学会海岸工学委員会（2000）：海岸施設設計便覧, 土木 学会, 582p.

土木学会海岸工学委員会（2002）：大蔵海岸陥没事故調査報 告書, 土木学会海岸工学委員会, p.125.

Mei, C.C. (1989) : The applied dynamics of ocean surface waves, World Scientific, Singapore, pp.199-206. 